\title{
Proses Penilaian Prestasi Kerja Pegawai Negeri Sipil Pada Kantor Unit Penyelenggara Bandar Udara
}

\author{
${ }^{1}$ Moh. Agus Suhartono, ${ }^{2}$ Tehubijuluw Zacharias, ${ }^{3}$ Faizal Madya \\ ${ }^{1,}{ }^{3}$ Universitas Terbuka \\ ${ }^{2}$ Universitas Kristen Indonesia Maluku \\ suhartonomohagus@gmail.com \\ tehubijuluwzacharias@yahoo.com \\ faizal@ecampus.ut.ac.id
}

\begin{abstract}
ABSTRAK
Tujuan penelitian adalah menganalisis identifikasi proses pada strategi SWOT yang dilakukan dalam perbaikan penilaian kerja pegawai, pada kantor Unit Penyelenggara Bandar Udara Karel Sadsuitubun. Penelitian ini merupakan penelitian kualitatif dengan pendekatan studi kasus terfokus. Pengumpulan data dilakukan melalui wawancara terbuka mendalam, observasi dan dokumentasi. Teknik analisis data dibatasi dengan menggunakan analisis SWOT (Strength, Weaknesses, Opportunities and Threats Analysis) sehingga dapat diketahui struktur dan tingkat strategi dari faktor-faktor tersebut. Dari hasil penyajian data dan analisis data dapat disimpulkan bahwa Penilaian kinerja petugas di Bandara Karel Sadsuitubun telah mengacu pada Peraturan yang berlaku serta dalam hal peningkatan Kompetensi Pimpinan dalam melaksanakan penilaian dilakukan melalui pelatihan atau workshop.
\end{abstract}

Kata Kunci: Evaluasi, Proses, Penilaian, Pencapaian Tugas.

\begin{abstract}
The purpose of the study was to analyze the identification of the process in the SWOT strategy which was carried out in improving employee performance appraisal, at the Karel Sadsuitubun Airport Organizing Unit office. This research is qualitative research with a focused case study approach. Data was collected through in-depth open interviews, observation, and documentation. The data analysis technique is limited by using SWOT analysis (Strength, Weaknesses, Opportunities, and Threats Analysis) so that the structure and strategic level of these factors can be known. From the results of data presentation and data analysis, it can be concluded that the performance appraisal of officers at Karel Sadsuitubun Airport has referred to the applicable regulations and in terms of improving Leadership Competence in carrying out the assessment, it is carried out through training or workshops.
\end{abstract}

Keywords: Evaluation, Process, Assessment, Task Achievement.

\section{PENDAHULUAN}

Penyelenggara pelayanan di Bandar udara sebagai pelayanan publik memiliki pedoman atau standar yang ditetapkan, yaitu Standar Pelayanan, waktu penyelesaian, anggaran operasional, produk pelayanan, sarana dan prasarana, serta kompetensi petugas pemberi pelayanan (Kepmenpan No.63/Kep/M.Pan/7/2003). Sebagai pengguna jasa masyarakat mengharapkan pelayanan publik yang disediakan oleh pemerintah sesuai dengan kebutuhan yakni ketersedian, kenyamaan, keamanan dan kehandalan sehingga bandar udara sebagai pelayanan publik dipacu dalam mengembangkan dan peningkatan pelayanan bagi masyarakat.

Kabupaten Maluku Tenggara dan Kota Tual merupakan daerah kepulauan, dimana akses keluar masuk hanya dapat ditempuh dengan menggunakan moda transportasi laut dan Udara. Bandar Udara Karel Sadsuitubun yang berlokasi di Kabupaten Maluku Tenggara melayani dua masyarakat pemerintahan daerah yakni kabupaten Maluku Tenggara dan Kota Tual. Dikarenakan letaknya yang strategis dan sangat penting bagi perekonomian masyarakat yang ada di Kabupaten Maluku Tenggara 
dan Kota Tual diharapkan kinerja operasional Bandar Udara Karel Sadsuitubun sangat diharapkan kehandalanya.

Kehandalan kinerja operasional Bandar udara tidak lepas dari faktor sumber daya manusia yang ada di dalam organisasi tersebut. Sehingga perlu adanya suatu standar kecakapan, pengetahuan dan keterampilan dalam menjalankan tugas. Seperti yang disampaikan Menteri Perhubungan Budi Karya Sumadi dalam Webinar dengan tema 'Transportasi Merajut Kebersamaan Episode 5: SDM Transportasi' yakni "perkembangan sektor transportasi tidak lepas dari peran sumber daya manusia sehingga sumber daya manusia menjadi faktor yang sangat penting”.

Bandar udara Karel Sadsuitubun yang telah beroperasi sejak tahun 2014 memiliki panjang landas pacu $2350 \mathrm{~m} \mathrm{X} 45 \mathrm{~m}$ yang mampu didarati Pesawat jenis Airbus 200 / Being 900 NG. Pelaksanaan operasional Bandar udara Karel Sadsuitubun mulai pukul 06.00 s/d 17.30 WIT dimana untuk saat ini melayani adalah berjadwal maskapai Wings Air dan Susi Air, pesawat militer dan pesawat komersil yang tidak berjadwal. Dengan jam operasional yang cukup panjang dan trafik lalu lintas udara yang dilayani, dibutuhkan sumber daya manusia yang profesional dalam operasional Bandar udara Karel Sadsuitubun. Sumber daya manusia sebagai faktor utama diharapkan memiliki kualitas dan kuantitas sesuai standar pelayanan. Dengan kata lain kinerja pegawai Bandar udara Karel Sadsuitubun dituntut lebih profesional dalam menjalankan pelayanan publik. Dengan keterbatasan jumlah pegawai yang dimiliki dibutuhkan kinerja yang maksimal dari setiap individu yang ada.

Menurut John (2007) Kinerja individu merupakan pondasi kinerja organisasi. Masalah kinerja pegawai sangat menentukan keberhasilan dalam tujuan organisasi dalam hal ini Bandar udara. Kinerja mengandung pengertian sesuatu yang dapat dilakukan oleh seseorang atau kumpulan orang-orang dalam suatu perkumpulan sesuai dengan wewenang dan kewajiban setiap pegawai.. Sehingga untuk memenuhi kepentingan organisasi dalam meningkatkan dan mengevaluasi kinerja pegawai perlu dilaksanakan penilaian kinerja pegawai yang dilaksanakan oleh organisasi Peraturan Pemerintah No 46 tahun 2011 tentang Penilaian Prestasi Kerja Pegawai Negeri Sipil.

Pengamatan peneliti melihat tingkat pelanggaran disiplin pegawai cukup tinggi dengan indikator:

1. Pulang dan datang tidak sesuai dengan jadwal yang diberikan,

2. Meninggalkan unit kerja pada saat jam kerja,

3. Mengambil cuti melebihi jumlah hari yang diberikan pimpinan.

4. Kurang efektif dalam bekerja.

Dengan kondisi di atas kami melihat hasil penilaian prestasi kerja pegawai kantor unit penyelenggara Bandar udara Karel Sadsuitubun tidak sesuai dengan kondisi dilapangan, ini dapat dilihat dengan penilaian yang diberikan pimpinan selalu bernilai sempurna Dengan nilai rata-rata penilaian Prestasi Kerja pegawai selama tiga tahun sebagai berikut:

Tabel 1. Penilaian Prestasi Kerja Pegawai Kantor Bandara Karel Sadsuitubun

\begin{tabular}{cccccccc}
\hline TAHUN & NILAI SKP & $\begin{array}{c}\text { ORIENTASI } \\
\text { PELAYANAN }\end{array}$ & INTEGRITAS & KOMITMEN & DISIPLIN & KERJASAMA & KEPEMIMPINAN \\
\hline 2017 & 86.86 & 81.59 & 81.5 & 81.39 & 81.44 & 81.65 & 87.11 \\
\hline 2018 & 86.86 & 79.58 & 81.44 & 81.27 & 81.45 & 81.46 & 86.54 \\
\hline 2019 & 95.68 & 80.93 & 80.98 & 80.98 & 78.53 & 81.10 & 86.59 \\
\hline
\end{tabular}

Sumber Data: Data Base Kepegawaian Kantor Bandara Karel Sadsuitubun

Berdasarkan pada latar belakang dalam hasil penilaian prestasi kerja dan kualitas kinerja pegawai Bandar udara Karel Sadsuitubun dapat disimpulkan terdapat permasalahan dalam proses penilaian prestasi kerja pegawai yang tidak sesuai dengan prinsip kaidah penilaian kerja pegawai negeri sipil yakni Peraturan Pemerintah no 46 Tahun 2011 Tentang Penilain Prestasi Kerja Pegawai Negeri Sipil dan Peraturan Kepala Badan Kepegawaian Negara No. 1 Tahun 2013 ketentuan pelaksanaan PP no 46 tahun 2011 tentang penilaian prestasi kerja PNS. 


\section{METODE PENELITIAN}

Dalam pelaksanaan penelitian menggunakan metode kualitatif deskriptif, yang bertujuan untuk memberikan gambaran suatu gejala atau fenomena di lapangan. Bentuk instrumen penelitian digunakan diantaranya: penelitian sebelumnya, catatan observasi, hasil wawancara, dokumentasi serta beberapa dokumen lain yang mendukung penelitian. Analisa SWOT dalam penelitian ini digunakan dalam pemetaan isu dan faktor strategis dalam upaya penilaian prestasi kerja pegawai. Adapun alasan dalam penggunaan analisis SWOT adalah agar dapat diketahui struktur serta tingkat strategi di setiap factor yakni Strengths, Wearnesses, Opportunities, Threats, dalam menanggapi isu isu yang ditimbulkan. Teknik Analisis SWOT merupakan tahap awal dalam upaya menemukan isu strategi yang nantinya selalu berkaitan dalam permasalahan yang ditimbulkan dalam proses penilaian kinerja pegawai di lingkungan Kantor Unit Penyelenggara Bandar Udara Karel Sadsuitubun.

\section{HASIL DAN PEMBAHASAN}

Penilaian Kinerja Pegawai Negeri Sipil sebagai bagian dari pembinaan Pegawai Negeri Sipil sebagaimana yang diatur dalam Peraturan Nomor 46 Tahun 2011 yang memuat tentang Penilaian Prestasi Kerja Pegawai Negeri Sipil, diperkuat dengan Peraturan Kepala Badan Kepegawaian Negara Nomor 01 Tahun 2013 yang memuat tentang ketentuan pelaksanaan Peraturan Pemerintah Nomor 46 Tahun 2011 yang merupakan wujud dari pelaksanaan penilaian prestasi kerja Pegawai Negeri Sipil. Tujuan penilaian prestasi kerja Pegawai Negeri Sipil pada Kantor Unit Penyelenggara Bandar Udara Karel Sadsuitubun adalah untuk:

1) Mengetahui kemampuan pegawai dalam penguasaan pekerjaan;

2) Mengetahui sikap dan prilaku pegawai dalam bekerja;

3) Mengetahui tingkat loyalitas dan integritas seorang pegawai

4) Mengetahui tingkat efisiensi dan efektifitas pegawai;

5) Dalam rangka pembinaan pegawai

6) Pemberian reward dan punishment bagi seorang pegawai
Pelaksanaan penilaian prestasi kerja PNS di kantor Unit Penyelenggara Bandar udara Karel Sadsuitubun yang merupakan amanah dari ketentuan peraturan pemerintah Nomor 46 tahun 2011 tentang penilaian prestasi kerja dan Perka BKN Nomor 01 tahun 2013 tentang petunjuk teknis PP Nomor 46 tahun 2011. Sejak tahun 2014 PNS di lingkungan Kantor Unit Penyelenggara Bandar Udara Karel Sadsuitubun sudah menjalankan peraturan PP Nomor 46 tahun 2011 dengan sistem manual dan sejak tahun 2018 dibuatkan sistem aplikasi penilaian prestasi kerja guna membantu mempermudah pembuatan SKP , pelaporan realisasi dan proses penilaian.

Pelaksanaan proses penilaian prestasi kerja sebagai berikut:

1) Penilaian prestasi kerja dilakukan berdasarkan prinsip, objektif, terukur, akuntabel, partisipatif, dan transparan yang dilaksanakan oleh atasan langsung

2) Penilaian sasaran kerja pegawai dilakukan dengan cara membandingkan antara realisasi kerja dengan target yang dilakukan setiap bulannya sesuai dengan realisasi bulanan.

3) Penilaian perilaku kerja dilaksanakan oleh atasan langsung dengan melakukan pengamatan terhadap bawahannya sesuai dengan kriteria yang telah ditentukan.

Dari hasil penelitian observasi dan wawancara penilaian prestasi kerja dari unsur penilaian sasaran kerja pegawai (SKP) dan Perilaku kerja dihasilkan kendala dan permasalahan sehingga hasil dari penilaian prestasi kerja pegawai di kantor UPBU Karel Sadsuitubun kurang efektif.. Sehingga dilaksanakan analisa dengan menggunakan metode analisis SWOT. Analisa SWOT mengidentifikasi faktor kekuatan (strength) dan factor kelemahan (weakness) dalam faktor internal dalam organisasi, serta factor peluang (opportunity) dan Faktor ancaman (threat) merupakan faktor eksternal dari organisasi . Sehingga dari faktor tersebut diharapkan dapat menghasilkan identifikasi faktor penghambat dan peningkatan kinerja pegawai di lingkungan kantor UPBU Karel Sadsuitubun dalam proses penilaian kerja pegawai. 
326 Coopetition, Vol XII, Nomor 3, November 2021,

(E-ISSN : 2615-4978, P-ISSN : 2086-4620)

\section{Identifikasi Analisa SWOT}

1. Faktor Internal

Tabel 2. IFAS (Internal Strategic Factor Analysis Summary)

\begin{tabular}{|c|c|c|c|c|}
\hline Faktor Internal & Rating & Bobot & $\begin{array}{c}\text { Nilai } \\
\text { tertimbang }\end{array}$ & keterangan \\
\hline \multicolumn{5}{|l|}{ Kekuatan (Stranghiths) } \\
\hline Komitmen pemimpin & 5 & 1 & 5 & \\
\hline Sarana dan Prasarana & 3 & 0,9 & 2,7 & \\
\hline 3. Reward dan Punishment & 4 & 0,8 & 3,2 & \\
\hline$\underline{\text { Total }}$ & & & $\underline{10,9}$ & \\
\hline \multicolumn{5}{|l|}{ Kelemahan (Weaknesses) } \\
\hline $\begin{array}{l}\text { a. Adanya Subjektivitas dalam } \\
\text { Penilaian }\end{array}$ & 5 & 0,85 & 4,25 & \\
\hline $\begin{array}{l}\text { Keterbatasan kualitas Kompetensi } \\
\text { SDM }\end{array}$ & 4 & 0,5 & 2 & \\
\hline Total & & & $\underline{6,25}$ & \\
\hline
\end{tabular}

Sumber: data diolah.

- $\quad$ Skala Rating : Mulai 1 (Tidak Penting) s/d 5 (Sangat Penting)

- Bobot Faktor: Dari 1,0 (sangat dibutuhkan) s/d 0,0 (tidak dibutuhkan)
Dari data diatas disimpulkan bahwa strategi internal masih dapat ditingkatkan dengan cara mengoptimalkan kekuatan dan meminimalkan kelemahan misalnya dengan adanya peningkatan pengetahuan dan saling berkoordinasi dengan pimpinan yang lebih tinggi.

2. Faktor Eksternal

Tabel 3 EFAS (External Strategic Factor Analysis Summary)

\begin{tabular}{|c|c|c|c|c|}
\hline Faktor Eksternal & Bobot & Rating & $\begin{array}{c}\text { Nilai } \\
\text { tertimbang }\end{array}$ & keterangan \\
\hline \multicolumn{5}{|l|}{ Peluang (Opportunities) } \\
\hline a. Peraturan Perundang-undangan & 4 & 0.4 & 1,6 & \\
\hline b. Dukungan Pemerintah Pusat & & & & \\
\hline c. Informasi Teknologi & 3 & 0.5 & 1,5 & \\
\hline Total & 4 & 0.7 & $\begin{array}{l}2,8 \\
5,9 \\
\end{array}$ & \\
\hline \multicolumn{5}{|l|}{ Ancaman (Treats) } \\
\hline a. Perkembangan teknologi & 4 & 0,75 & 3 & \\
\hline b. Perubahan Peraturan & 3 & 0,5 & 1,5 & \\
\hline c. Sosial dan Politik & 2 & 0,25 & 0,5 & \\
\hline Total & & & $\underline{5}$ & \\
\hline
\end{tabular}

Sumber: data diolah. 
- $\quad$ Skala Rating : Mulai 1 (Tidak Penting) s/d 5 (Sangat Penting)

- Bobot Faktor: Dari 0,1 (sangat dibutuhkan) s/d 0,0 (tidak dibutuhkan)

Setelah menegetahui nilai tetimbang dan total utuk vareabel maka langkah selanjutnya menentukan posisi organisasi dalam satu kuadran dari empat kuadran yang ada dalam matrik SWOT sekaligus strategi selanjutnya. Dari hasil perhitungan di atas terdapat selisih dari nilai tertimbang adalah sebagai berikut:

Tabel 4. Selisih Nilai Tertimbang

\begin{tabular}{lc}
\hline Nilai tertimbang Kekuatan (Stranghiths) & 10,9 \\
Nilai Tertimbang Kelemahan (Weaknesses) & 6,25 \\
Selisih Positif & $\mathbf{4 , 6 5}$ \\
Nilai tertimbang Peluang (Opportunities) & 5,9 \\
Nilai Tertimbang Ancaman (Treats) & 5 \\
Selisih Positif & $\mathbf{0 , 9}$ \\
\hline
\end{tabular}

Sumber : Data diolah.

Dari hasil perhitungan selisih nilai tertimbang pada yabel 4 di atas, kekuatan dengan nilai tertimbang kelemahan dihasilkan selisih positif 4,65 dan selisih nilai pertimbnagan peluang dengan nilai tertimbang ancaman juga selisih positif 0,9 maka disimpulkan posisi organisasi berada pada kuadran I dan saran penggunaan strategi sesuai dengan kekuatan yang dimiliki dan besarnya peluang yang masih tersedia.

Dari hasil perhitungan selisih nilai tertimbang kekuatan kelemahan dihasilkan selisih positif. Sehingga dapat digambarkan posisi peta organisasi sebagai berikut:

\section{Peluang}

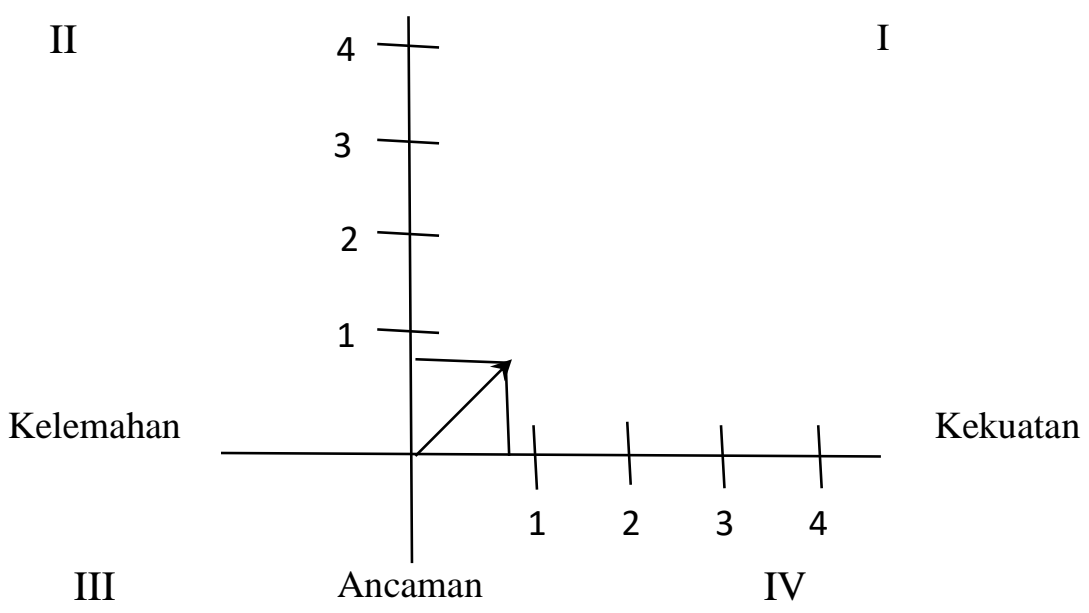

\section{Gambar 1. Peta Posisi Kekuatan dan Peluang Organisasi}

Terkait posisi organisasi dihasilkan selisih pertimbangan bernilai positif dengan terletak pada Kuadran I dengan point 4,65 dan 0,9 dengan strategi sesuai dengan kekuatan dan besarnya peluang yang dimiliki organisasi. Dari hasil analisa SWOT dapat diimplementasikan Pimpinan UPBU Karel Sadsuitubun dalam melaksanakan perbaikan dan 
peningkatan kualitas penilaian prestasi kerja pegawai UPBU Karel Sadsuitubun.

\section{Strategi Analisa SWOT}

Dari hasil Analisis SWOT yang dilakukan, maka dapat dilaksanakan strategi dalam upaya perbaikan penilaian Prestasi Kerja Pegawai di Kantor UPBU Karel Sadsuitubun antara lain :

a. Membangun Komitmen Pemimpin dalam melaksanakan penilaian yang secara profesioanal yang jujur, objektif dan tranparan;

b. Peningkatan kompetensi Pimpinan dalam pelaksanaan Penilaian Prestasi Kerja Pegawai dengan mengikuti diklat atau workshop dalam upaya perbaiakan Penilaian Prestasi Kerja Pegawai;

c. Membangun komitmen dalam memajukan Sumber daya Manusia di Kantor UPBU karel Sadsuitubun; d. Membangun kerjasama antara pimpinan dan bawahan dalam rangka penyelenggaraan kegiatan Penilaian Prestasi Kerja;

e. Pemenuhan kebutuhan norma dan Prosedur sebagai upaya perbaikan Penilaian Prestasi Kerja Pegawai;

Untuk dapat memilih alternatif strategi yang paling baik dapat digunakan dilakukan dengan pembobotan. Pembobotan diwakilkan dengan nilai angka,. semakin tinggi nilai yang diperoleh menunjukan tingkatan strategi yang efektif. Nilai yang digunakan dalam pembobotan yakni:

Angka 1: Tidak baik

Angka 2: Kurang baik

Angka 3 : Cukup baik

Angka 4: Baik

Angka 5 : Sangat baik

Table 5. Skor Alternatif Strategi Analisa SWOT

\begin{tabular}{|c|c|c|c|c|c|c|c|}
\hline No & Alternatif Strategi & 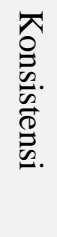 & 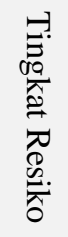 & 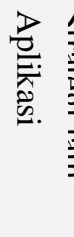 & 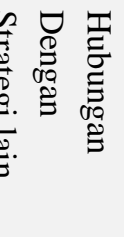 & 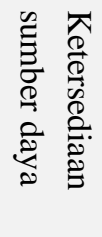 & 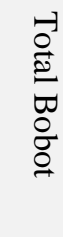 \\
\hline 1 & $\begin{array}{l}\text { Membangun Komitmen Pemimpin dalam } \\
\text { melaksanakan penilaian yang secara } \\
\text { profesional yang jujur, objektif dan } \\
\text { transparan }\end{array}$ & 5 & 4 & 3 & 4 & 4 & 20 \\
\hline 2 & $\begin{array}{l}\text { Peningkatan kompetensi Pimpinan dalam } \\
\text { pelaksanaan Penilaian Prestasi Kerja } \\
\text { Pegawai dengan mengikuti diklat atau } \\
\text { workshop dalam upaya perbaikan } \\
\text { Penilaian Prestasi Kerja Pegawai }\end{array}$ & 3 & 4 & 2 & 4 & 4 & 17 \\
\hline 3 & $\begin{array}{l}\text { Membangun komitmen dalam memajukan } \\
\text { Sumber daya Manusia di Kantor UPBU } \\
\text { karel Sadsuitubun }\end{array}$ & 3 & 4 & 3 & 3 & 4 & 15 \\
\hline 4 & $\begin{array}{l}\text { Membangun kerjasama antara } \\
\text { dan bawahinan } \\
\text { penyelenggaraan } \\
\text { Prestasi Kerja }\end{array}$ & 4 & 3 & 2 & 4 & 3 & 16 \\
\hline 5 & $\begin{array}{l}\text { Pemenuhan kebutuhan norma dan Prosedur } \\
\text { sebagai upaya perbaikan Penilaian Prestasi } \\
\text { Kerja Pegawai }\end{array}$ & 3 & 4 & 1 & 5 & 3 & 16 \\
\hline
\end{tabular}

Sumber: data diolah.

Dari hasil analisis strategi didapatkan nilai tertinggi didapat pada strategi Membangun Komitmen
Pemimpin dalam melaksanakan penilaian yang secara profesional yang jujur, objektif dan 
transparan. Artinya dalam upaya perbaikan penilaian prestasi kerja pegawai di kantor UPBU Karel Sadsuitubun dengan melaksanakan pembangunan komitmen dari para pemimpin sehingga diharapkan dengan pembangunan komitmen tersebut akan menghasilkan penilaian prestasi kerja pegawai yang
(1) Objektif
(2)Terukur,
(3)Akuntabel, (4)Partisipatif, dan (5)Transparan. Namun demikian, hal ini bukan berarti alternatif strategi lain tidak penting dikembangkan dan tidak memerlukan sumber daya yang berkualitas juga. Sebagai upaya dalam menyeimbangkan pelaksanan peningkatan penilaian prestasi kerja pegawai pemanfaatan alternatif strategi sebagai upaya lain apabila alternatif pertama tidak berjalan sesuai yang diharapkan.

Berdasarkan hasil analisis SWOT yang telah dilakukan, maka dapat dilaksanakan strategi dalam upaya perbaikan penilaian Prestasi Kerja Pegawai di Kantor UPBU Karel Sadsuitubun antara lain :

1. Membangun Komitmen Pemimpin dalam melaksanakan penilaian yang secara profesioanal yang jujur, objektif dan tranparan;

2. Peningkatan kompetensi Pimpinan dalam pelaksanaan Penilaian Prestasi Kerja Pegawai dengan mengikuti diklat atau workshop dalam upaya perbaiakan Penilaian Prestasi Kerja Pegawai;

3. Membangun komitmen dalam visi bersama mencapai tujuan pembangunan sumber daya manusia di Kantor UPBU karel Sadsuitubun;

4. Membangun kerjasama antara pimpinan dan bawahan dalam rangka penyelenggaraan kegiatan Penilaian Prestasi Kerja;

5. Pemenuhan kebutuhan norma dan Prosedur sebagai upaya perbaikan Penilaian Prestasi Kerja Pegawai;

\section{SIMPULAN DAN SARAN}

\section{Simpulan}

Berdasarkan hasil penyajian data dan analisis data, maka dapat disimpulkan bahwa Peraturan Pemerintah Nomor 46 tahun 2011 dan Peraturan Kepala Badan Kepegawaian Negara Nomor 01 Tahun 2013 tentang Penilaian prestasi kerja pegawai telah dilaksanakan sesuai dengan aturan pada Unit Penyelenggara Bandar Udara Karel Sadsuitubun. Penilaian prestasi kerja memiliki tujuan dalam upaya perbaikan kinerja pegawai di Kantor Unit Penyelenggara Bandar Udara Karel Sadsuitubun dimana fokus penilaian pada hasil dan perilaku pegawai. Pelaksanaan penilaian prestasi kerja terkait sasaran kerja pegawai masih belum sesuai dikarenakan keterbatasan pegawai sehingga pegawai memiliki lebih dari satu tugas pokok jabatan, sehingga dari kondisi tersebut mempengaruhi penilaian atau atasan langsung dalam melaksanakan penilaian perilaku kerja pegawai.

\section{Saran}

Berdasarkan uraian pada simpulan, maka dapat disarankan beberapa hal oleh peneliti kepada pengambil kebijakan terutama di Unit Penyelenggara Bandar Udara Karel Sadsuitubun terkait penilaian prestasi kerja sebagai berikut:

1. Diperlukannya pelatihan bagi Pimpinan Kantor Unit Penyelenggara Bandar Udara Karel Sadsuitubun terkait proses penilaian prestasi kerja pegawai.

2. Diperlukan adanya sosialisasi terkait PP 46 Tahun 2011 Tentang penilaian prestasi kerja pegawai kepada Seluruh pegawai Kantor Unit Penyelenggara Bandar Udara Karel Sadsuitubun terkait proses, tujuan dan manfaat penilaian prestasi kerja pegawai.

3. Diperlukan Standar Penialain dalam acuaan proses Penilaian presatasi kerja di Kantor Unit Penyelenggara Bandar Udara Karel Sadsuitubun guna mempermudah proses penilaian prestasi kerja .

4. Diperlukan koordinasi dan komunikasi berbagai pihak yang terkait proses penilaian prestasi kerja pegawai yakni Atasan Langsung, Para Pejabat, Pengelola kepegawain dan pimpinan di unit kerja.

5. Diperlukan ketegasan sebagai Atasan langsung dalam memberikan hukuman disiplin dan pembinan bagi anggota apalila melanggaran kedisiplianan.

6. Penilaian prestasi kerja Pegawai Negeri Sipil perlu dilakukan secara berkala evaluasi dan didokumentasikan dengan rapi dalam arsip kepegawaian setiap orang sehingga tidak ada informasi yang hilang baik bersifat menguntungkan maupun merugikan pegawai.

\section{DAFTAR PUSTAKA}

A.A. Anwar Prabu Mangkunegara. 2006. Evaluasi Kinerja Sumber Daya Manusia. Jakarta: Refika Aditama

A.W. Widjaja, 2006, Administrasi Kepegawaian, Jakarta, Rajawali.

Badriyah, Mila. 2015. Manajemen Sumber daya Manusia. Bandung: CV Pustaka Setia

Bambang Prasetyo, Miftahul Jannah, Metode Penelitian Kuantitatif Teori dan Aplikasi, Jakarta: PT. Raja Grafindo Persada, 20 
Budianto (2018).Evaluasi Kinerja Aparatur Sipil Negara Dinas Kehutanan pemerintahan Pemerintahan Provinsi Sulawesi Barat. Jakarta: Tugas Akhir Program magister,Magister Ilmu Administrasi Universitas Terbuka

Griffin (2009).Bisnis \& Birokrasi, Jurnal Ilmu Administrasi dan organisasi sept-Des 2009: 131139

Handoko, T., Hani, 1998, Manajemen dan Sumber Daya Manusia, Yogyakarta, Liberty.

Keban, Yeremias T. (2014). Enam Dimensi Strategis Administrasi Publik: Konsep, Teori dan Isu. Yogyakarta: Gava Media

Manulang, M. 1981. Manajemen Kepegawaian. Penerbit Sinar Harapan, Medan.

Martoyo, S. 2003. Manajemen Sumber Daya Manusia, BPFE, Yogyakarta.

Nitisemito, A. S. 1983. Manajemen Personalia.Penerbit. Ghalia Indonesia, Jakarta.

Pamudji, S. 1982. Ekologi Administrasi Negara, Bumi Aksara, Jakarta.

Rangkuti, Freddy. 2004. Manajemen Persediaan Aplikasi di Bidang Bisnis. Jakarta : PT. Raja Grafindo Persada

Rangkuti, Freddy. ((2009). Strategi Promosi yang Kreatif dan Analisis Kasus Integrated Marketing Communication. Jakarta : $\quad$ PT. Gramedia Pustaka Utama

Rahmat, Mamat (2006), penilaian Pelaksanan pekerjaan Pegawai negeri Sipil. Jakarta: Badan Kepegawaian Negara. Pusat pendidikan dan pelatihan Kepegawaian.

Rahmat, Mamat (2012). Sasaran Kinerja Pegawai. Jakarta: Badan Kepegawaian Negara, Pusat Pendidikan dan Pelatihan Kepegawaian.

Rokhmawati, Puspita (2013). Analisis Penilaian Prestasi Kerja Pegawai.Jurnal Dinamika Manajemen, JDM Vol.4 No.1,2013,pp23-29

Rivai, H.V dan Sagala, J.E. 2009. Manajemen Sumberdaya Manusia untuk Perusahaan dari Teori ke Praktek. Edisi Kedua.Penerbit Rajawali Press. Jakarta.

Ruky, 2001. Sistem manajemen Kinerja : Panduan Praktis untuk merancang kinerja Prima. PT. Gramedia Pustaka Utama Jakarta.
Siagian, S.P. 1983. Peran Staf dalam Manajemen.Penerbit Gunung Agung Jakarta.

Siagian, S.P.2002 . Manajemen Sumber Daya Manusia. Penerbit Bumi Aksara Jakarta

Singarimbun, M. dan Effendy. S. 1989. Metode Penelitian Survey.Penerbit LP3ES. Jakarta

Soeprihanto. (2009). Manajemen Sumber Daya Manusia Lanjutan. Yogyakarta

Sm,Chusminah dan Haryati,R.Ati (2019). Analisis Penelitian Kinerja pegawai Pada bagian kepegawaian dan Umum Direktorat jenderal P2P kementerian kesehatan. Jurnal Sekretaris dan manajemen Widya Cipta Volume 3 No 1 maret 2019 P-ISSN 2550-0805 E-ISSN 2550-0791

Sugiyono. 2009. Metode Penelitian Administrasi Dilengkapi Metode R\&D. Penerbit Alfabeta Bandung.

Supranto. J. 2008 Statistik, Teori dan Aplikasi Jilid 2. Penerbit Erlangga, Jakarta

Sutrisno (2009), Budaya Organisasi, Kencana: Surabaya

Suriani, Ni Kadek (2018) Evaluasi Kinerja Pegawai Dinas Transmigrasi Provinsi Sulawesi Barat. Jakarta: Tugas Akhir Program magister,Magister Ilmu Administrasi Universitas Terbuka

T. Hani Handoko,. 2005. Manajemen Personalia dan Sumber Daya Manusia. Yogyakarta : BPFE.

Widodo, Erna Dan Mukhtar, 2000, Konstruksi Ke Arah Penelitian Deskriptif, Avirouz, Yogyakarta.

Wijayanti, Annisa dan Supra Wimbarti (2012). Evalusi dan Penegmbangan sistim penilaian Kinerja pada PT HKS. Jurnal Psikologi Undip Vol. 11, No 2

Undang- undang Republik Indonesia Nomor 5 Tahun 2014 Tentang Aparatur Sipil Negara.

Peraturan Pemerintah Republik Indonesia No 46 tahun 2011 tentang Penilaian Kinerja Pegawai Negeri Sipil.

Peraturan Pemerintah Republik Indonesia Nomor 11 tahun 2017 tentang Manajemen Pegawai Negeri Sipil.

Keputusan Menteri Perhubungan Republik Indonesia Nomor KM 155 Tahun 2019 Tentang Peta Jabatan dan Uraian Jenis Kegiatan Jabatan Unit Pelaksana Teknis di Lingkungan Direktorat Jenderal Perhubungan Udara 